\title{
Intestinal Transport of Water and Electrolytes during Extracellular Volume Expansion in Dogs
}

\author{
James T. Higgins, JR., and Norman P. Blair \\ From the Department of Medicine, Indiana University School of Medicine, \\ Indianapolis, Indiana 46202
}

\begin{abstract}
A в S T R A C T The effects of extracellular fluid volume expansion on intestinal transport of salts and water were studied in dogs by perfusing loops of bowel in vivo. Saline loading caused depression of duodenal and jejunal absorption with net secretion of salt and water into the lumen. Studies of unidirectional transport of ${ }^{22} \mathrm{Na}^{+}$revealed that the negative net sodium flux was due primarily, and perhaps exclusively, to increased serosal to mucosal transport, for mucosal to serosal sodium transport was not changed during volume expansion. Net transport of water and potassium paralleled net sodium flux. Administration of deoxycorticosterone did not affect the intestinal response to saline loading. Hemodilution, accomplished by equilibrating the dogs' blood with a reservoir of saline, did not affect intestinal absorption, but isotonic, iso-oncotic expansion of the extracellular fluid produced by reinfusing the saline-blood mixture from the reservoir resulted in negative net transport of water, sodium, and potassium by the duodenum. It is suggested that the small bowel is capable of secreting salts and water through intercellular spaces, and that this process is stimulated by extracellular fluid volume expansion.
\end{abstract}

\section{INTRODUCTION}

Over the past decade a considerable amount of evidence has accumulated indicating that variation in net tubular reabsorption of sodium, independent of glomerular filtration rate or mineralocorticoid hormone level, is an important factor in the control of renal sodium excretion (1-5). Under the conditions of saline loading (6,

This work was presented in part at the 4th Annual Meeting of the American Society of Nephrology and at the $\mathrm{Na}$ tional Meeting of the American Federation for Clinical Research, May 1971.

Dr. Higgins is the recipient of Research Career Development Award HE-42403 from the National Heart and Lung Institute.

Received for publication 17 May 1971.
7) or escape from the sodium-retaining activity of mineralocorticoid hormones (8), a marked decrease in net sodium reabsorption has been demonstrated in the proximal tubule of the kidney, and it has been postulated that a circulating hormone may be responsible for a major part of the control of tubular reabsorption (2, $5,9-11)$.

Evidence for a humoral substance which controls tubular reabsorption is largely indirect. Moreover, the anatomy of the kidney makes it extremely difficult to carry out direct measurement of tubular transepithelial fluxes under anything approaching physiologic conditions. For this reason, and working on the assumption that a hormone which inhibits sodium transport by the kidney might also inhibit transport by other epithelial membranes, investigators have turned to sodium transport by toad bladder (11), frog skin $(12,13)$, and intestinal epithelium $(14,15)$. Two recent reports have shown that saline loading decreases net sodium absorption from the small intestine of the rat (14) and cat (15). In the studies carried out on rats, it was shown that net negative flux of salt and water occurred during saline loading, but unidirectional fluxes were not carried out to determine the mechanisms which determine the net transepithelial transport. The present experiments were carried out to investigate further the effects of saline loading on net salt and water absorption from the intestine of the dog, and to determine by examination of unidirectional flux of sodium the mechanism by which diminished net absorption occurs.

\section{METHODS}

Large mongrel dogs of both sexes were maintained on an ad libitum diet of commercial dog chow. Approximately 18 $\mathrm{hr}$ before experimentation, food was removed. On the morning of the study, the dogs were anesthetized with sodium pentobarbital, $30 \mathrm{mg} / \mathrm{kg}$ intravenously, with additional $60 \mathrm{mg}$ injections as needed to maintain light anesthesia. The trachea was intubated, but the dogs were not mechanically ventilated unless necessary. Cannulas were inserted into a femoral artery for monitoring blood pres- 
sure and for sampling blood, and into one or more peripneral veins for injections. The abdomen was opened and large Tygon ${ }^{1}$ cannulas with multiple side openings were inserted and ligated in the proximal and distal ends of segments of duodenum, jejunum, and colon. The intestines were returned to the abdominal cavity and the abdomen was closed about the cannulas. The gut segments were rinsed until clear with saline, then with Ringer's solution $\left(\mathrm{Na}^{+}, 150 ; \mathrm{K}^{+}, 5 ; \mathrm{Cl}^{-}, 156\right.$; and $\mathrm{HCO}_{3}{ }^{-}, 3, \mathrm{mEq} /$ liter, respectively). Ringer's solution, containing $100 \mathrm{mg} / 100 \mathrm{ml}$ polyethylene glycol (PEG), ${ }^{2}$ a nonabsorbable marker, and ${ }^{22} \mathrm{Na}^{+}$in tracer quantities, was perfused at $3.8 \mathrm{ml} / \mathrm{min}$ simultaneously through all three gut segments. The effluent flowed by gravity from each segment into flasks. After a 30 -min equilibration period, three 20 -min control samples were collected and then the dogs were studied during either of two experimental protocols. 17 dogs were saline loaded, 4 of these after pretreatment with deoxycorticosterone acetate (DOCA), and 11 underwent hemodilution followed by volume expansion and then hemorrhage. The perfusate and all samples were assayed for PEG by a turbidimetric method (16), for $\mathrm{Na}^{+}$and $\mathrm{K}^{+}$by flame photometry, and for $\mathrm{Cl}^{-}$by a coulometric method. Sodium-22 was counted in a well-type counter. Blood was collected at midpoint of all periods for determination of $\mathrm{Na}^{+}, \mathrm{K}^{+}, \mathrm{Cl}^{-}$, total protein (17), and hematocrit.

In saline-loading experiments, control samples were collected as described above, and then three 20 -min collections were made over the next hour during which the dog received an intravenous infusion of $0.9 \% \mathrm{NaCl}$ in a volume equal to $10 \%$ of its weight. Four dogs received DOCA, 10 $\mathrm{mg}$ intramuscularly, on the evening before and again on the morning of the experiment.

In 11 other dogs, control collections were made and then three 20 -min collections were made while the animal underwent isovolemic hemodilution. Blood was pumped from a femoral vein into a beaker containing approximately 2 liters of warmed $\left(37^{\circ} \mathrm{C}\right)$, stirred saline. The blood-saline mixture was returned to the opposite femoral vein at the same rate (Harvard bidirectional peristaltic pump ${ }^{3}$ ). By this method, hematocrit and plasma protein were significantly reduced without extracellular fluid expansion. Intestinal fluxes were then studied during three 20-min periods of isotonic, iso-oncotic extracellular fluid volume expansion. This was accomplished by stopping blood withdrawal and returning to the dog over a 60 -min period all of the blood-saline mixture from the beaker. In four of the dogs, intestinal fluxes were further studied during extracellular fluid volume contraction, produced by withdrawal of sufficient blood to maintain the dog's systolic blood pressure at approximately $90 \mathrm{~mm} \mathrm{Hg}$.

In five studies of unidirectional sodium fluxes during saline loading, the isotopic $\mathrm{Na}$ was injected into the animal rather than placed in the gut perfusate. To help maintain the isotope within the animal, nephrectomy was carried out just before the experiment was begun. In this series of experiments, fluxes were determined in the duodenum only.

Calculations were carried out on a small computer (Olivetti Programma $101^{4}$ ) utilizing a program based on the following equations. Since PEG is not absorbed from the

\footnotetext{
${ }^{1}$ Norton Company, Plastics and Synthetics Div., Akron, Ohio.

${ }^{2}$ Abbreviations used in this paper: DOCA, deoxycorticosterone acetate; PEG, polyethylene glycol.

${ }^{8}$ Harvard Apparatus Co., Inc., Millis, Mass.

- Olivetti Underwood Corp., New York.
}

gut, its concentration goes up if water is absorbed and down if water is secreted so that

$$
\text { per cent } \begin{aligned}
\mathrm{H}_{2} \mathrm{O} \text { absorption } & =100\left(1-\frac{[\mathrm{PEG}]_{\mathrm{i}}}{[\mathrm{PEG}]_{0}}\right), \text { and } \\
\text { net } \mathrm{H}_{2} \mathrm{O} \text { flux } & =\text { flow }_{\mathrm{i}} \times\left(1-\frac{[\mathrm{PEG}]_{\mathrm{i}}}{[\mathrm{PEG}]_{0}}\right),
\end{aligned}
$$

where $[P E G]_{1}$ represents PEG concentration of the perfusate entering the gut segment, $[\mathrm{PEG}]_{\text {o the }}$ concentration in the effluent, and flow ${ }_{1}$ the rate of flow of perfusate into the gut segment. For any ion or other solute,

net solute flux $=\left(\right.$ Hlow $_{\mathrm{i}} \times\left[\right.$ solute $\left._{\mathrm{i}}\right)-\left(\right.$ flow $\left._{0} \times[\text { solute }]_{0}\right)$.

Lnidirectional fluxes of $\mathrm{Na}^{+}$, utilizing ${ }^{22} \mathrm{Na}^{+}$, are calculated from

$$
\mathrm{M} \rightarrow \mathrm{S} \mathrm{Na}{ }^{+} \text {flux }=\left(1-\frac{\mathrm{cpm}_{\mathrm{i}}}{\mathrm{cpm}_{0}}\right) \times\left[\mathrm{Na}^{+}\right]_{\mathrm{i}} \times \text { flow }_{\mathrm{i}}
$$

and,

$$
\mathrm{S} \rightarrow \mathrm{M} \mathrm{Na}^{+} \text {flux }=\mathrm{M} \rightarrow \mathrm{S} \mathrm{Na}^{+} \text {flux }- \text { net } \mathrm{Na} \text { flux. }
$$

$\mathrm{M} \rightarrow \mathrm{S}$ flux is used to indicate uptake from the gut lumen into the animal's tissues, or mucosal to serosal movement. $\mathrm{S} \rightarrow \mathrm{M}$ flux indicates movement from the animal into the gut lumen, or serosal to mucosal movement, and brackets indicate concentration. For concentrations or flow rates, the subscripts $i$ and $o$ represent the perfusate going into or the effluent coming out of the gut segment. For comparison among animals, flux rates are factored by the weight of the gut segment perfused, and the end result expressed as quantity/minute per gram tissue. A more complete derivation of these equations is found in Levinson and Schedl, 1966 (18), and a discussion of PEG as a marker appears in Fordtran, 1966 (19).

All data from groups of animals are expressed as means \pm one SD. Significance of differences between means were calculated by the $t$ test, using the paired-data method where indicated (20).

\section{RESULTS}

Saline loading experiments. During 24 control periods in eight dogs, there was a small net absorption of water in the duodenum and jejunum with net fluxes of $1.91 \pm 3.50 \mathrm{SD}$ and $2.20 \pm 3.72 \mu \mathrm{l} / \mathrm{min}$ per $\mathrm{g}$ respectively (Fig. 1). During saline loading there was a visible increase in the effluent volume which was confirmed by progressively decreased PEG concentrations reflecting significant decreases of net water flux to $-12.84 \pm 10.87$ $\mu \mathrm{l} / \mathrm{min}$ per $\mathrm{g}(P<0.005)$ in the duodenum and -5.76 $\pm 4.96 \mu \mathrm{l} / \mathrm{min}$ per $\mathrm{g}(P<0.05)$ in the jejunum. The variability among animals was large, resulting in large standard deviations, but there was a progressive decrease in net water flux to negativity in every animal. Water flux in the colon was extremely variable among animals and showed no significant changes with saline loading.

Net sodium flux during control periods was 0.24 $\pm 0.54 \mu \mathrm{Eq} / \mathrm{min}$ per $\mathrm{g}$ in the duodenum and $0.25 \pm 0.45$ $\mu \mathrm{Eq} / \mathrm{min}$ per $\mathrm{g}$ in the jejunum (Fig. 2). During saline loading, there was a progressive decrease in net sodium 


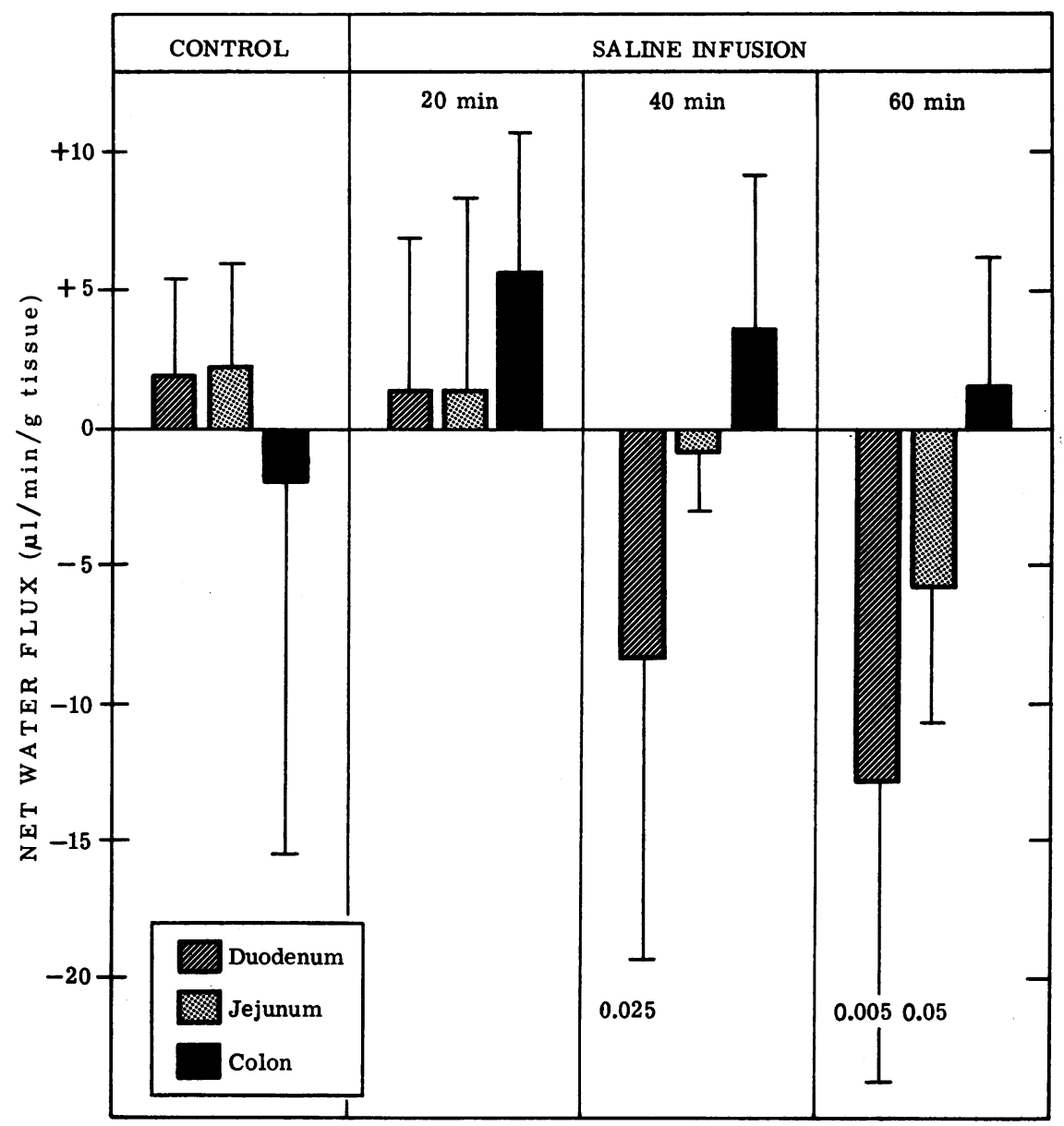

Figure 1 Net water flux across intestinal epithelium before and during three 20 min periods of intravenous saline loading. Upgoing bars indicate mean net absorption from the gut lumen and downgoing bars indicate mean net secretion from extracellular fluid into gut lumen. Value of one standard deviation is indicated by lines extending from the bars. Numbers under bars indicate $P$ value.

flux in both gut regions, becoming negative and paralleling net water flux. Duodenal net sodium flux became significantly different from control during the second period of saline loading $(-1.19 \pm 1.62 \mu \mathrm{Eq} / \mathrm{min}$ per $\mathrm{g}$, $P<0.05)$ and reached $-2.00 \pm 1.88(P<0.01)$ in the third period. Jejunal net sodium flux did not become significantly different from control until the third saline loading period $(-0.93 \pm 0.97, P<0.05)$. Net sodium flux in the colon, like water flux, did not change significantly with saline loading.

Unidirectional sodium fluxes, determined by uptake of ${ }^{22} \mathrm{Na}^{+}$from the perfusate are illustrated in Fig. 3 . The mucosal to serosal $(M \rightarrow S)$ flux of sodium is indicated by the upgoing bars and serosal to mucosal $(\mathrm{S} \rightarrow \mathrm{M})$ flux by the downgoing bars. The sum of these two processes, net sodium flux, is again indicated by the filled bars as in Fig. 2. It is seen that there was no change in $\mathrm{M} \rightarrow \mathrm{S}$ flux, and the net negative flux which occurred in the duodenum and jejunum during saline loading can be explained by the development of large fluxes of sodium into the gut lumen.

Since the $S \rightarrow M$ sodium flux is a highly derived value, based on calculations of net water flux, net sodium flux, and $\mathrm{M} \rightarrow \mathrm{S}$ sodium flux, five additional saline loading experiments were carried out in nephrectomized dogs given intravenous injections of ${ }^{22} \mathrm{Na}^{+}$to allow more direct calculation of the $\mathrm{S} \rightarrow \mathrm{M}$ sodium flux. Table I presents the duodenal water and sodium fluxes observed in these studies, as well as those obtained in the eight dogs described above in which the ${ }^{22} \mathrm{Na}^{+}$was placed in the perfusate. The results are clearly similar: during saline loading significantly negative net water and net sodium fluxes developed, and the negative net sodium flux is due to an increase in $\mathrm{S} \rightarrow \mathrm{M}$ flux, with $\mathrm{M} \rightarrow \mathrm{S}$ flux remaining unchanged.

The sodium concentration and osmolality of the per- 


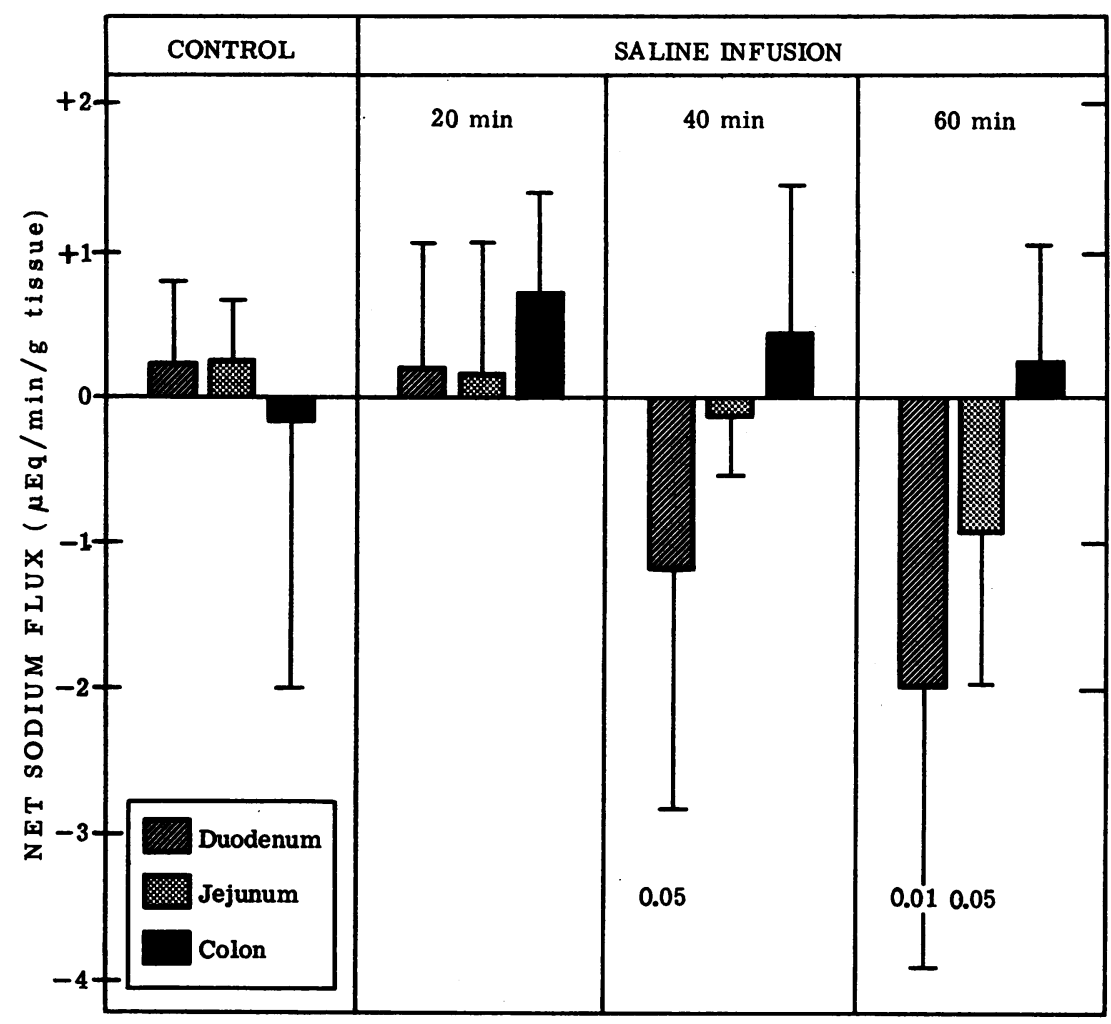

FIgURE 2 Net sodium flux across intestinal epithelium before and during saline loading. Interpretation of directional movements as in Fig. 1. Numbers under bars indicate $P$ values.

fusate did not change significantly during its course through any of the three gut segments.

Changes in net potassium flux during saline loading in the duodenum and jejunum paralleled changes in net water and sodium fluxes (Fig. 4). During control observations, net potassium flux averaged $0.003 \pm 0.010$ $\mu \mathrm{Eq} / \mathrm{min}$ per $\mathrm{g}$ in the duodenum and $0.001 \pm 0.017 \mu \mathrm{Eq} /$ min per $\mathbf{g}$ in the jejunum. Saline loading caused a significant fall to $-0.061 \pm 0.053 \mu \mathrm{Eq} / \mathrm{min}$ per $\mathrm{g}(P$ $<0.01)$ in the duodenum and $-0.044 \pm 0.041 \mu \mathrm{Eq} /$ min per $\mathrm{g}(P<0.05)$ in the jejunum.

Under both control and saline loaded conditions, the net potassium flux of the colon was negative (Fig. 4). During saline loading the degree of negativity became progressively greater although these changes were not statistically significant due to the large standard deviations.

The potassium concentration of the perfusate did not change during its course through the duodenum and jejunum, but the concentration of the effluent from the colon during control $(5.42 \pm 0.34 \mathrm{mEq} / \mathrm{liter})$ was significantly above that of the perfusate $(4.99 \pm 0.41 \mathrm{mEq} /$ liter, $P<0.025)$, and it rose significantly to $6.06 \pm 0.93$ $\mathrm{mEq} /$ liter $(P<0.05)$ during saline loading. The move- ment of potassium into the gut lumen occurred against a concentration gradient from plasma to perfusate (Table II).

The mean hematocrit was $48.9 \pm 4.4 \%$ during control and fell by an average of $31 \%$ of the control value to $34.0 \pm 7.3 \%$ in the last saline-loading period. Plasma sodium concentration did not change during saline loading, but plasma potassium concentration fell from a control value of $4.14 \pm 0.47 \mathrm{mEq} / \mathrm{liter}$ to $2.70 \pm 0.72$ $\mathrm{mEq} /$ liter in the last period of saline loading (Table II).

The dogs became hypothermic during saline loading and to eliminate the possibility that hypothermia was influencing the results, temperature was controlled and monitared in four dogs placed on heating pads and given warmed $\left(37^{\circ} \mathrm{C}\right)$ saline. The intestinal fluxes were the same as in the dogs allowed to become hypothermic, and the results are pooled in the data presented above.

To rule out the unlikely possibility that negative gut fluxes were caused by a fall in endogenous mineralocorticoid hormone levels associated with saline loading, four dogs were given deoxycorticosterone $10 \mathrm{mg}$ intramuscularly on the evening before and again the morn- 


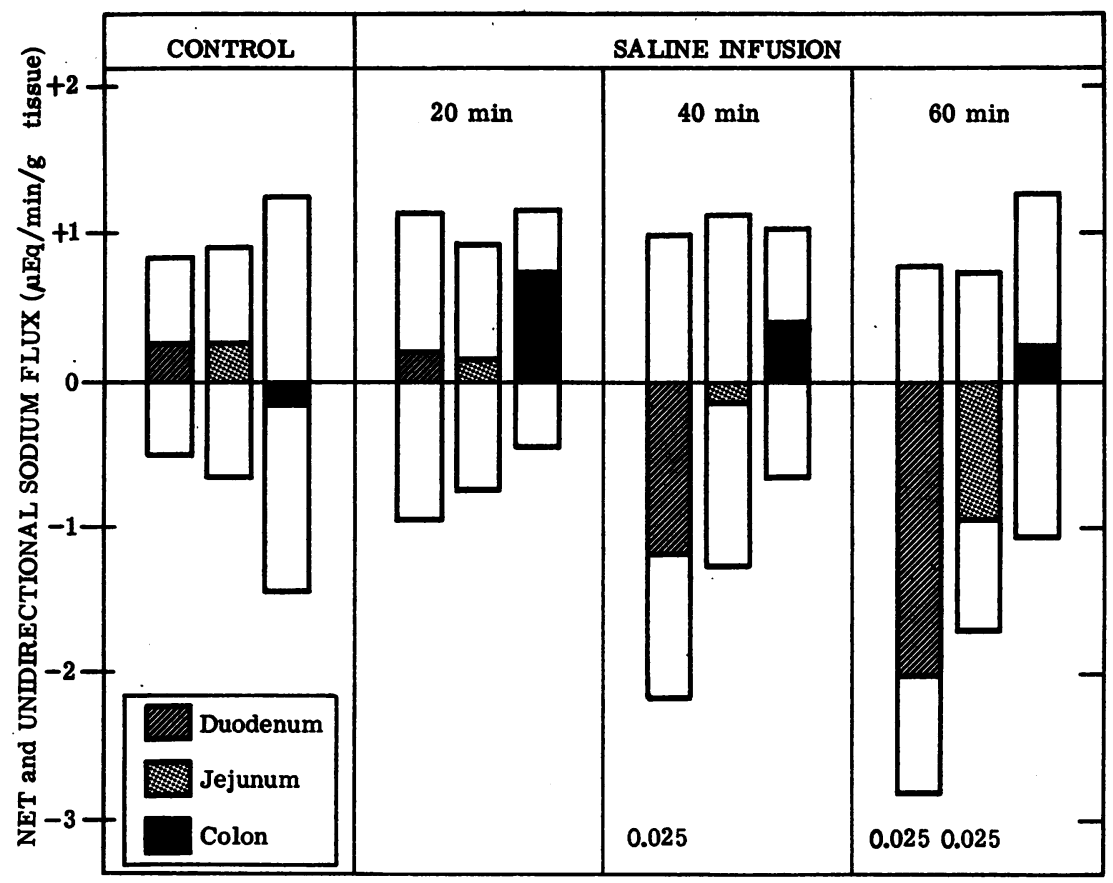

FIGURE 3 Net and unidirectional fluxes of sodium across intestinal epithelium before and during saline loading. Upgoing open bars indicate influx rate from lumen into extracellular fluid, downgoing open bars indicate simultaneous outflux rate from extracellular fluid into gut lumen, and filled bars again indicate net flux rate as in Fig. 1. Numbers under bars indicate $P$ values.

ing of the experiment. As shown in Fig. 5, the results were similar to those obtained in dogs not given deoxycorticosterone.

Hemodilution-reinfusion experiments. Saline loading causes dilution of the blood at the same time that it is expanding the extracellular fluid, and the effect of each of these factors on gut absorption was studied. 11 dogs underwent isovolemic hemodilution, produced by equilibrating the dog's blood with 2 liters of saline extracorporeally over a $1-\mathrm{hr}$ period. The blood was significantly hemodiluted, as evidenced by decreases in hematocrit and plasma protein concentration, but water and electrolyte fluxes in the duodenum were un- changed from values seen during control periods (Fig. 6 and Table III). Mean arterial blood pressure fell to $73.0 \pm 15.4 \mathrm{~mm} \mathrm{Hg}$ from a control value of $136.5 \pm 19.9$ $(P<0.001)$; there was a slight drop in plasma potassium concentration from $3.52 \pm 0.30 \mathrm{mEq} / \mathrm{liter}$ to $3.30 \pm 0.40$, and a slight but significant rise in plasma sodium concentration from $149.8 \pm 3.8 \mathrm{mEq} / \mathrm{liter}$ to $151.9 \pm 3.9(P<0.01)$.

To produce isotonic, iso-oncotic plasma volume expansion, the saline-blood mixture in the flask was next pumped into the dog over a $1-\mathrm{hr}$ period during which three 20-min observations were made. The hematocrit and plasma protein concentration remained unchanged,

TABLE I

Duodenal Water and Sodium Fluxes as Determined with Isotopic Sodium in Gut Perfusate or Infused Intravenously

\begin{tabular}{|c|c|c|c|c|c|}
\hline & & Net $\mathrm{H}_{2} \mathrm{O}$ flux & Net Na flux & $\mathrm{M} \rightarrow \mathrm{S}$ Na flux & $\mathrm{S} \rightarrow \mathrm{M}$ Na flux \\
\hline \multirow{3}{*}{${ }^{22} \mathrm{Na}$ in perfusate, $\mathrm{n}=8$} & & $\mu \mathrm{l} / \mathrm{min} / \mathrm{g}$ & $\mu E q / \min / g$ & $\mu E q / \min / g$ & $\mu E q / \min / g$ \\
\hline & Control (mean $\pm \mathrm{SD}$ ) & $1.91 \pm 3.50$ & $0.24 \pm 0.54$ & $0.82 \pm 0.65$ & $0.52 \pm 0.26$ \\
\hline & Saline load & $-12.84^{*} \pm 10.87$ & $-2.00^{*} \pm 1.88$ & $0.81 \pm 0.43$ & $2.21^{*} \pm 1.12$ \\
\hline${ }^{22} \mathrm{Na}$ in plasma, $\mathrm{n}=5$ & Control & $1.10 \pm 1.08$ & $0.15 \pm 0.13$ & $0.51 \pm 0.11$ & $0.36 \pm 0.03$ \\
\hline · & Saline load & $-7.99^{*} \pm 4.09$ & $-1.09^{*} \pm 0.52$ & $0.53 \pm 0.14$ & $1.53 \pm 0.64$ \\
\hline
\end{tabular}

* Different from control value at $P<0.02$. 


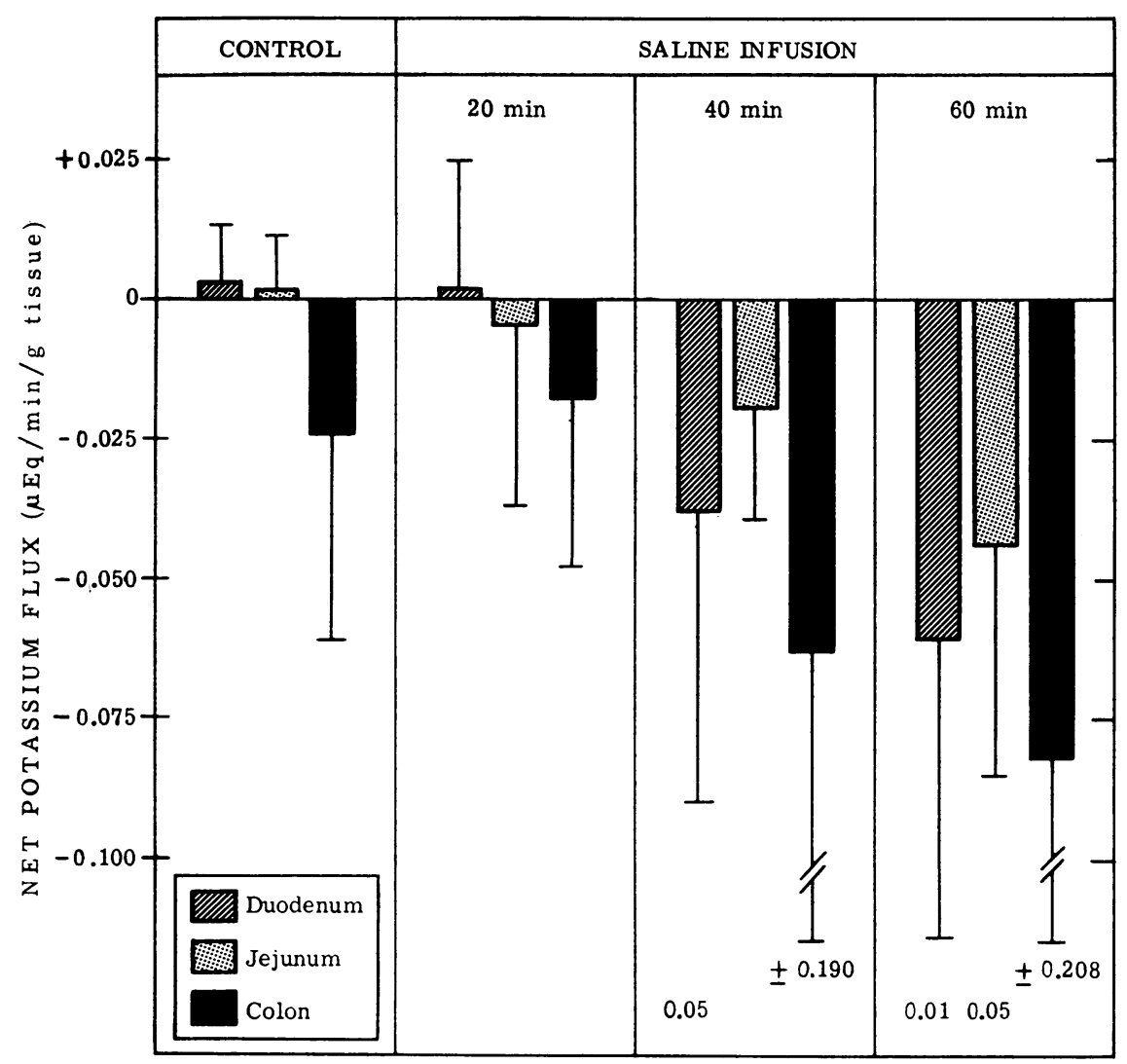

Figure 4 Net potassium flux across intestinal epithelium before and during saline loading. Interpretation of directional movements as in Fig. 1. Numbers under bars indicate $P$ values.

but the net sodium and water fluxes fell. becoming negative in the first reinfusion period, and by the second reinfusion period were significantly different from the last hemodilution period (Fig. 6 and Table III). The fall in net sodium flux appears to be due primarily to significantly increased serosal to mucosal flux, for although there is a slight fall in the average mucosal to serosal flux, this change is not significant. The

TABLE II

Potassium Concentration in Plasma, Perfusate, and Effluent from Colon during Control and Three 2()-min Periods of Saline Loading

\begin{tabular}{lcccc}
\hline & & \multicolumn{4}{c}{ Saline infusion } \\
& Control & $20 \mathrm{~min}$ & $40 \mathrm{~min}$ & $60 \mathrm{~min}$ \\
& & \multicolumn{4}{c}{$m q^{\prime}$ liter } \\
Plasma & $4.14 \pm 0.47$ & $3.32 \pm 0.29$ & $2.80 \pm 0.28$ & $2.70 \pm 0.72$ \\
Perfusate & $4.99 \pm 0.41$ & $4.99 \pm 0.41$ & $4.99 \pm 0.41$ & $4.99 \pm 0.41$ \\
Effluent & $5.42 \pm 0.34^{*}$ & $5.66 \pm 0.56$ & $5.89 \pm 0.82$ & $6.06 \pm 0.93 \ddagger$
\end{tabular}

* Significantly different from perfusate entering colon, $P<0.025$.

$\ddagger$ Significantly different from mean concentration of eftluent during control, $P<0.05$. mean arterial blood pressure rose to $115.9 \pm 15.1 \mathrm{~mm}$ $\mathrm{Hg}$ during the last hemodilution period $(P<0.001)$. but remained lower than the control pressure of 136.5 \pm 19.9 . Plasma sodium and potassium concentrations remained essentially unchanged.

To be sure that the intestinal mucosil was still capable of normal absorption after the long experimental observation, four dogs were hemorrhaged, reaching an average mean arterial pressure of $86.2 \pm 27.8 \mathrm{~mm} \mathrm{Hg}$. In every animal there was an increase in net water and sodium absorption, and as shown in Fig. 6 and Table III, the mean increases for the group were significant $(P<0.025)$. There appeared to be an increased mucosal to serosal and a lecreased serosal to mucosal flux, but these changes were not significant due to the small number of observations. The intestinal nucosa, therefore, appears capable of absorbing sodium and water normally throughout the experiment.

It should be pointed out that although for any individual sodium flux calculation it is assumed that the net flux is the algebraic sum of the two unidirectional fluxes, this exact equality cannot be expected for 
the mean flux values of the entire group of animals as presented in Fig. 6 and Table III.

Plasma protein determinations were done only in the last four experiments to determine whether changes in hematocrit accurately indicate the degree of dilution of plasma proteins. As indicated in Fig. 6 and 7, there was good agreement; hematocrits ranging from 28 to $52 \%$ and plasma proteins of $2.7-9.0 \mathrm{gm} / 100 \mathrm{ml}$ showed a high degree of correlation $(r=0.96, P<0.01)$.

\section{DISCUSSION}

The significance of these studies is best understood by first considering the current concepts of renal sodium excretion by animals in the salt-loaded state. As pointed out in several recent reviews on the subject, the central issue involves control of tubular reabsorption $(4,5$, 21 ), and there is experimental evidence that a humoral substance may mediate sodium excretion by blocking renal tubular reabsorption (2, 5, 9-14). Such a natriuretic hormone, whose existence is strongly advocated by some investigators and equally strongly denied by others, would presumably exert its effect on net sodium reabsorption by blocking active transport in the mucosal to serosal direction. Working on the assumption that a substance which blocks transport in the renal tubule may also block other sodium-transporting membranes, several groups of investigators have turned to nonrenal tissues in an effort to find evidence for the natriuretic hormone. Richet and Hornych demonstrated negative net sodium fluxes across the jejunum of saline loaded rats and offered this finding as evidence for a humoral inhibitor of sodium transport in the gut and in the renal tubule (14). Although these authors did not speculate on the mechanism by which saline loading diminishes sodium absorption, three possibilities exist. Unidirectional mucosal to serosal flux might be reduced to a level below the simultaneous serosal to mucosal flux, serosal to mucosal flux might increase to exceed mucosal to serosal flux, or a combination of both processes might occur.

The presently reported studies not only confirm the development of negative net fluxes across the small intestinal mucosa, but indicate that the diminished intestinal salt and water absorption which occurs during extracellular volume expansion is due primarily, and perhaps exclusively, to increases in serosal to mucosal movement of sodium. Movement of sodium in the opposite direction, from mucosa to serosa, does not appear to be changed during saline loading. During isosmotic, iso-oncotic plasma volume expansion (Fig. 6) there may have been a diminution of the mucosal to serosal flux, but the differences were not statistically significant, and are surpassed by the significant increases in serosal to mucosal flux.
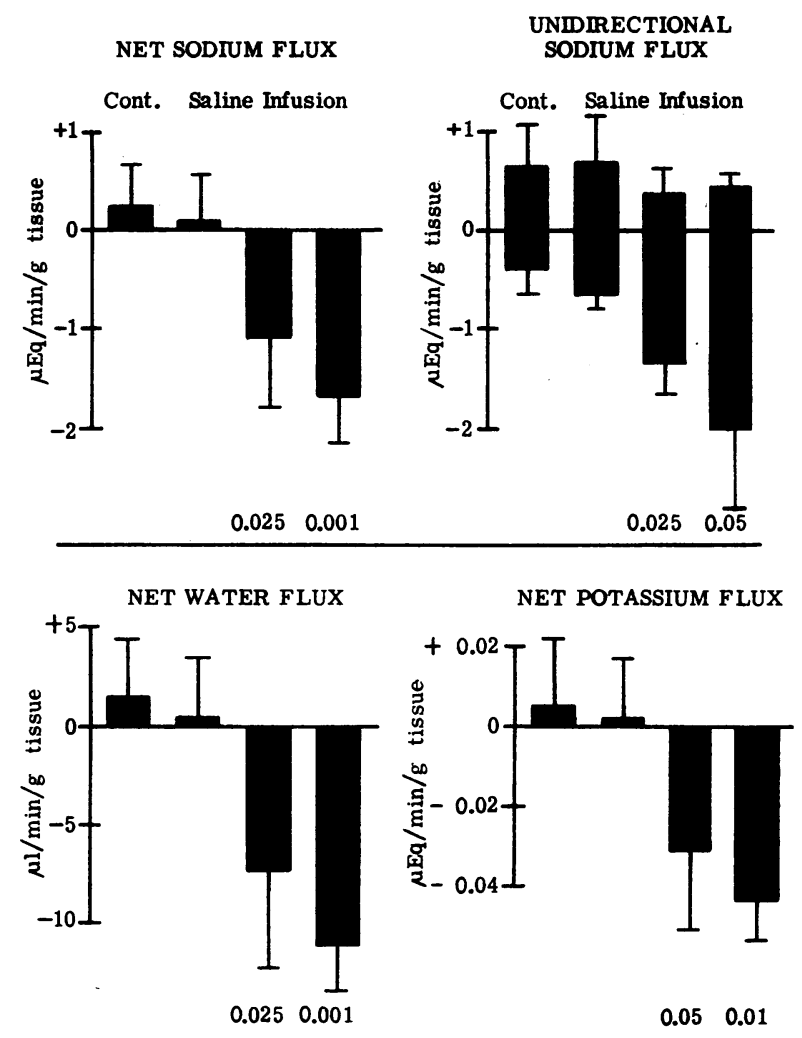

Figure 5 Net and unidirectional fluxes of sodium and net water and potassium fluxes before and during saline loading in the duodenum of dogs treated with deoxycorticosterone. The first bar of each graph indicates mean control flux, and the three subsequent bars indicate fluxes during saline loading; interpretation of directional movements as in Figs. 1 and 3. Numbers under bars indicate $P$ values.

Although the turbidimetric assay method for PEG is not notably precise, there seems to be no reason to doubt these results. In the first place, there was an obvious increase in the volume of effluent from the gut segments during volume expansion. The volume coming out of the segments exceeded the volume pumped in and this can only be explained by movement of fluid into the lumen from the extracellular fluid of the dog. Secondly, a series of unpublished experiments has been carried out in this laboratory using PEG $-{ }^{14} \mathrm{C}$, in addition to unlabeled $\mathrm{PEG}$, as a marker and the water fluxes calculated from changes in concentration of the two markers showed a high degree of correlation $(r=0.845, P<0.01)$. The base line duodenal net sodium flux, determined by change in PEG concentration and calculated in terms of surface area, of $10.42 \pm 5.15 \mu \mathrm{Eq} / \mathrm{cm}^{2}$ per $\mathrm{hr}$ agrees well with other published values $(22,23)$.

The negative net fluxes which were observed. during extracellular fluid expansion are not due to hypothermia or damage to the intestinal mucosa because experi-

Intestinal Transport during ECF Expansion 2575 
ments during which body temperature was maintained gave similar results, and because hemorrhaging the dog at the end of the experiment resulted in restoration of positive duodenal net fluxes. Preliminary studies in dogs in which extracellular fluid volume expansion was produced with bicarbonate Ringer solution demonstrated negative duodenal net water and electrolyte fluxes; the plasma $\mathrm{pH}$ in these animals was shown to be normal and constant. Thus, the acidosis which accompanies saline infusion is not the cause of the negative intestinal fluxes. Finally, the unidirectional sodium fluxes show good agreement in studies carried out with ${ }^{22} \mathrm{Na}^{+}$in the extracellular fluid instead of in the perfusate.

Therefore, it is believed that the present findings are accurate and physiologically significant. They disagree with the studies of Gutman and Benzakein, which showed decreased mucosal to serosal and unchanged serosal to mucosal sodium fluxes in ileal segments of the saline loaded cat (15). There were many differences between the preparations presently reported and that of Gutman and Benzakein, who did not observe negative net sodium fluxes across the intestinal epithelium of saline-loaded animals as reported here and by Richet and Hornych as well (14).

Although bidirectional sodium transport has been extensively studied in a number of tissues, most theoretical models appear to have been proposed to explain changes in net transport in terms of the unidirectional flux thought to best characterize the physiologic function of the epithelium involved, i.e., mucosal to serosal flux in the case of absorptive structures such as the intestine and renal tubule, or serosal to mucosal flux in the case of secretory structures such as the avian salt gland and the insect malpighian tubule. No model has been found in the literature which would explain the findings of the studies presented here, although bidirectional fluxes have been documented in the intestine (22-24), kidney (25-29), frog skin (30), toad bladder (31), and gill (32). The apparent independence of mucosal to serosal and serosal to mucosal flux demonstrated here and in the studies of Visscher et al. (22, 23 ), and the unequal unidirectional osmotically driven fluxes of sucrose through the frog skin (33), and of water through the frog intestine (24), both suggest that different pathways are involved, but offer no insight about whether those pathways are transcellular or intercellular. A third possibility in the intestine, of course, is glandular secretion.

One can only speculate at the present time about whether the increased serosal to mucosal transport of water and salts observed in these studies during extracellular fluid volume expansion proceeds along transcellular, intercellular, or glandular pathways. Whether or not one believes the intercellular "tight junctions" (34) to be impervious to ions and water, the constant mucosal to serosal transport observed here would presumably be moving along the lateral intercellular spaces according to the well-accepted standing gradient hypothesis (35) and would not be compatible with a large flux of sodium, potassium, and water in the serosal to mucosal direction through the same lateral intercellular spaces. It has been

TABLE III

Duodenal Fluxes, Hematocrit, and Plasma Protein

\begin{tabular}{|c|c|c|c|c|c|}
\hline & \multirow{2}{*}{$\begin{array}{l}\text { Mean } \\
\text { control }\end{array}$} & \multicolumn{4}{|c|}{ Hemodilution } \\
\hline & & 1 & 2 & & 3 \\
\hline Net Na flux, $\mu E q / \min / g$ & $\begin{array}{c}0.37 \pm 0.46 \\
(\mathrm{n}=11)\end{array}$ & $0.42 \pm 0.60$ & $\begin{array}{c}0.22 \pm 0.60 \\
(n=11)\end{array}$ & 0.31 & \pm 0.72 \\
\hline $\mathrm{M} \rightarrow \mathrm{S} \mathrm{Na}$ flux, $\mu E q / \min / g$ & $\begin{array}{c}1.09 \pm 0.55 \\
(n=11)\end{array}$ & $1.14 \pm 0.70$ & $\begin{array}{c}1.14 \pm 0.83 \\
(\mathrm{n}=9)\end{array}$ & 1.20 & \pm 0.54 \\
\hline $\mathrm{S} \rightarrow \mathrm{M} \mathrm{Na}$ flux, $\mu E q / \min / g$ & $\begin{array}{c}0.70 \pm 0.35 \\
(n=11)\end{array}$ & $0.71 \pm 0.29$ & $\begin{array}{c}0.84 \pm 0.27 \\
(\mathrm{n}=9)\end{array}$ & 0.69 & \pm 0.32 \\
\hline Net $\mathrm{H}_{2} \mathrm{O}$ flux, $\mu \mathrm{l} / \mathrm{min} / \mathrm{g}$ & $\begin{array}{c}2.78 \pm 3.52 \\
(n=11)\end{array}$ & $2.67 \pm 4.67$ & $\begin{array}{c}1.57 \pm 4.79 \\
(\mathrm{n}=11)\end{array}$ & 1.99 & \pm 5.57 \\
\hline Hematocrit, $\%$ & $\begin{array}{c}48.1 \pm 5.1 \\
(n=11)\end{array}$ & $42.6 \pm 6.0$ & $\begin{array}{c}37.2 \S \pm 6.7 \\
(\mathrm{n}=11)\end{array}$ & $35.1 \S$ & \pm 6.8 \\
\hline Plasma protein, $\mathrm{g} / 100 \mathrm{ml}$ & $\begin{array}{l}7.26 \pm 0.90 \\
(n=4)\end{array}$ & $6.02 \pm 0.59$ & $\begin{array}{c}3.93 \& \pm 0.30 \\
(n=4)\end{array}$ & $3.08 \S$ & \pm 0.25 \\
\hline
\end{tabular}

* Different from control value at $P<0.005$.

$\ddagger$ Different from control value at $P<0.02$.

\$ Different from control value at $P<0.002$. 


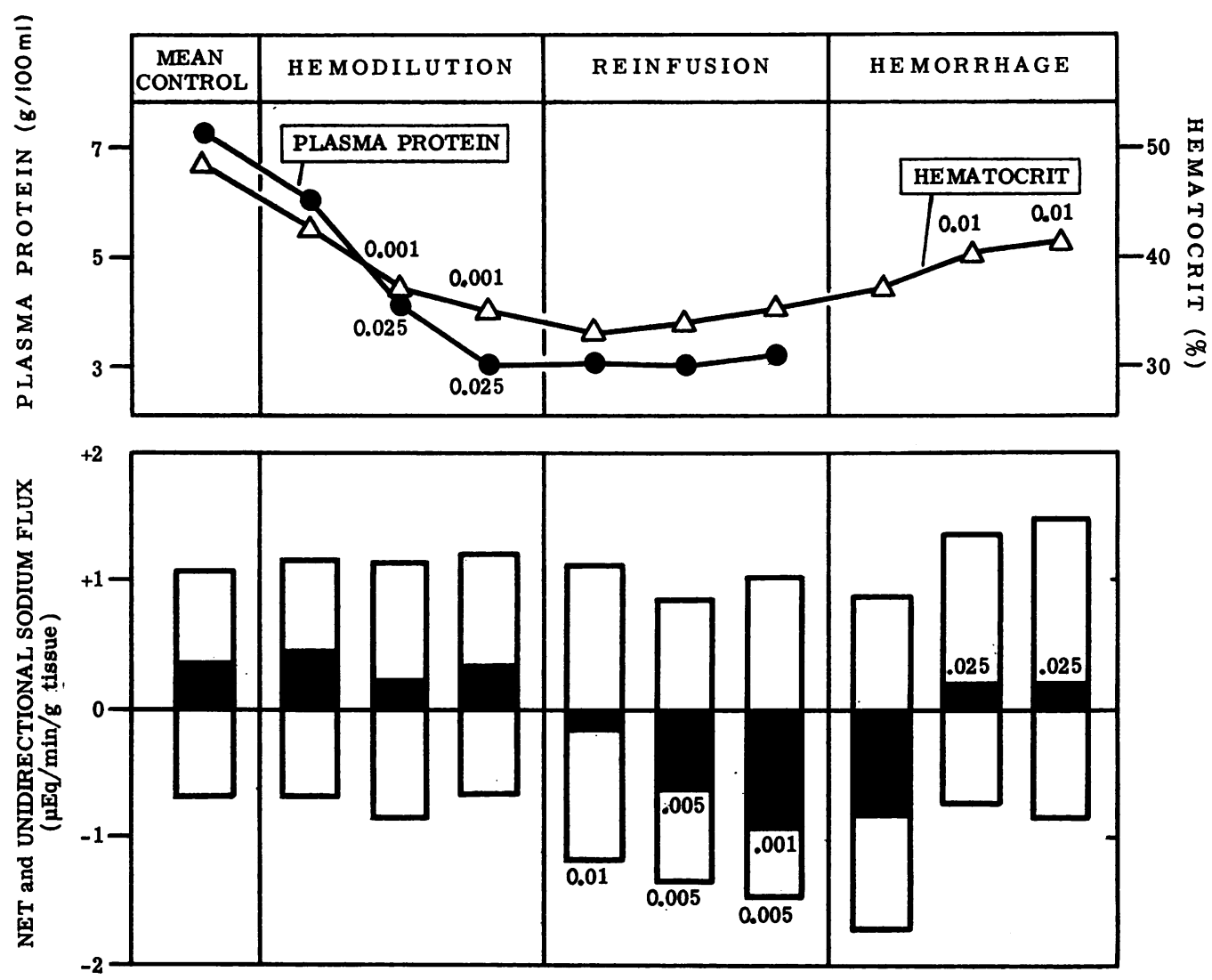

FIGURE 6 Changes in hematocrit, plasma protein concentration, and duodenal sodium flux during control, isovolemic hemodilution, extracellular fluid expansion by infusion of dilute blood, and during hemorrhage. Interpretation of bar graphs as in Fig. 3. Numbers on bars and adjacent to points on line graphs indicate $P$ values.

during Hemodilution, Reinfusion, and Hemorrhage

\begin{tabular}{|c|c|c|c|c|c|}
\hline \multicolumn{3}{|c|}{ Reinfusion } & \multicolumn{3}{|c|}{ Hemorrhage } \\
\hline 1 & 2 & 3 & 1 & 2 & 3 \\
\hline$-0.16 \pm 0.72$ & $\begin{array}{c}-0.65^{*} \pm 0.86 \\
(n=11)\end{array}$ & $-0.96^{*} \pm 0.95$ & $-0.88 \pm 0.77$ & $\begin{array}{c}0.20 \ddagger \pm 1.06 \\
(n=4)\end{array}$ & $0.20 \ddagger \pm 0.94$ \\
\hline $1.12 \pm 0.68$ & $\begin{array}{l}0.86 \pm 0.68 \\
(\mathrm{n}=9)\end{array}$ & $1.01 \pm 0.51$ & $0.88 \pm 0.48$ & $\begin{array}{c}1.37 \pm 0.63 \\
(\mathrm{n}=3)\end{array}$ & $1.49 \pm 0.31$ \\
\hline $1.20 \pm 0.45$ & $\begin{array}{l}1.34^{*} \pm 0.34 \\
(\mathrm{n}=9)\end{array}$ & $1.49^{*} \pm 0.32$ & $1.72 \pm 0.27$ & $\begin{array}{c}0.77 \pm 0.44 \\
(\mathrm{n}=3)\end{array}$ & $0.87 \pm 0.23$ \\
\hline$-1.03 \pm 4.80$ & $\begin{array}{l}4.26^{*} \pm 5.95 \\
(\mathrm{n}=11)\end{array}$ & $-5.95^{*} \pm 6.58$ & $-4.14 \pm 4.41$ & $\begin{array}{c}2.37 \ddagger \pm 5.97 \\
(n=4)\end{array}$ & $2.32 \ddagger \pm 6.15$ \\
\hline $33.1 \pm 6.3$ & $\begin{array}{c}34.0=5.9 \\
(\mathrm{n}=11)\end{array}$ & \pm 5.6 & $36.8 \pm 10.2$ & $\begin{array}{c}40.2 \ddagger \pm 8.9 \\
(n=4)\end{array}$ & $41.0 \ddagger \pm 8.3$ \\
\hline $3.17 \pm 0.42$ & $\begin{array}{c}2.97 \pm 0.28 \\
(n=4)\end{array}$ & $3.35 \pm 0.21$ & & & \\
\hline
\end{tabular}




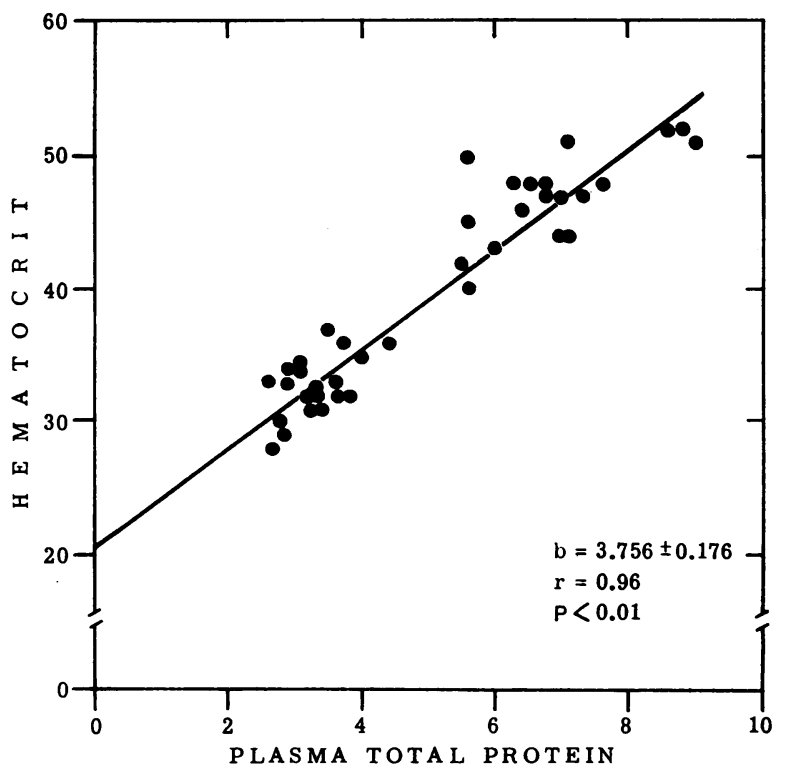

Figure 7 Plot of hematocrit and plasma protein concentration obtained simultaneously on blood samples from dogs undergoing hemodilution. Slope $(b)$, correlation coefficient $(r)$ and significance $(P)$ are indicated.

postulated, however, that in some secreting epithelia, such as the choroid plexus, the insect malpighian tubule, and the avian salt gland, there is a backward-functioning standing-gradient mechanism in the lateral intercellular spaces $(35,36)$. Heterogeneity of lateral membrane transport mechanism among the intercellular spaces of the small intestine, with both forward-functioning (mucosal to serosal) and backward-functioning (serosal to mucosal) transport through different intercellular spaces, is one possible explanation for the results reported here. This attractive hypothesis is supported by other experimental observations. Diamond has pointed out that backward-functioning channels would serve as an osmotic filtration mechanism for nontransported solutes (35), and the preliminary reports from this (37) and another laboratory (38) indicating serosal to mucosal transport of such nontransported molecules as creatinine and inulin during extracellular fluid volume expansion are consistent with the presence of such a filtration mechanism in the small intestine.

The driving force for the serosal to mucosal flux is not evident, but it does not appear to be either transepithelial ionic gradients nor changes in plasma oncotic pressure alone. The solution perfusing the gut in these studies was isotonic, and it was demonstrated that isotonic hemodilution fails to stimulate serosal to mucosal flux while isotonic, iso-oncotic extracellular fluid expansion is a strong stimulus. It is possible, however, that a combination of decreased osmotic pressure due to hemodilution, and increased hydrostatic pressure due to ex- tracellular fluid volume expansion, provide the necessary driving force. The arterial blood pressure fell during the studies of hemodilution, so that the decreased hydrostatic pressure may have offset the effect of the decreased oncotic pressure. During the reinfusion period of those studies, the oncotic pressure remained low while the hydrostatic pressure increased, and this combination of physical forces may have been responsible for the efflux of water and salts into the gut lumen. Diminished endogenous mineralocorticoid hormone level during volume expansion is probably not playing a role, since administration of large amounts of hormone in these studies and in those of Richet and Hornych (14) did not affect the results. Measurement of luminal potential might shed light on the transport mechanism, and such studies are in progress.

These studies do not offer evidence either for or against a humoral substance which is produced in response to extracellular fluid expansion, which is natriuretic, and which reduces net transepithelial sodium flux across the renal tubule or the intestinal mucosa. However, these findings do strongly suggest that if such a substance exists, it may act by stimulating unidirectional flux in the luminal direction, for in the intact dog extracellular fluid volume expansion causes a marked increase in serosal to mucosal sodium flux in the small intestine while producing no detectable change in mucosal to serosal sodium flux.

\section{ACKNOWLEDGMENTS}

The authors gratefully acknowledge the technical assistance of William J. Hathaway and Arthur Harris.

These studies were supported by U. S. Public Health Service Grants HE-06308 and HE-11638 and by a grant from the Marion County Chapter of the Indiana Heart Association.

\section{REFERENCES}

1. Levinsky, N. G., and R. C. Lalone. 1963. The mechanism of sodium diuresis after saline infusion in the dog. J. Clin. Invest. 42: 1261.

2. Davis, J. O., J. E. Holman, C. C. J. Carpenter, J. Urquhart, and J. T. Higgins, Jr. 1964. An extra-adrenal factor essential for chronic renal sodium retention in presence of increased sodium-retaining hormone. Circ. Res. 14: 17.

3. Lewy, J. E., and E. E. Windhager. 1968. Peritubular control of proximal tubular fluid reabsorption in the rat kidney. Amer. J. Physiol. 214: 943.

4. Earley, L. E., and T. M. Daugharty. 1969. Sodium metabolism. N. Engl. J. Med. 281: 72 .

5. de Wardener, H. E. 1969. Control of sodium reabsorption. Brit. Med. J. 3: 611, 676.

6. Watson, J. F. 1966. Effect of saline loading on sodium reabsorption in the dog proximal tubule. Amer. J. Physiol. 210: 781 .

7. Hayslett, J. P., M. Kashgarian, and F. H. Epstein. 1967. Changes in proximal and distal tubular reabsorp- 
tion produced by rapid expansion of extracellular fluid. J. Clin. Invest. 46: 1254.

8. Wright, F. S., F. G. Knox, S. S. Howards, and R. W. Berliner. 1969. Reduced sodium reabsorption by the proximal tubule of DOCA-escaped dogs. Amer. J. Physiol. 216: 869.

9. Johnston, C. I., and J. O. Davis. 1966. Evidence from cross circulation studies for a humoral mechanism in the natriuresis of saline loading. Proc. Soc. Exp. Biol. Med. 121: 1058.

10. Bricker, N. S., S. Klahr, M. Purkerson, R. G. Schultze, L. V. Avioli, and S. J. Birge. 1968. In vitro assay for a humoral substance present during volume expansion and uraemia. Nature (London). 219: 1058.

11. Buckalew, V. M., F. J. Martinez, and W. E. Green. 1970. The effect of dialysates and ultrafiltrates of plasma of saline-loaded dogs on toad bladder sodium transport. J. Clin. Invest. 49: 926.

12. Nutbourne, D. M., J. D. Howse, R. W. Schrier, L. B. Talner, M. G. Ventom, P. J. Verroust, and H. E. de Wardener. 1970. The effect of expanding the blood volume of a dog on the short-circuit current across an isolated frog skin incorporated in the dog's circulation. Clin. Sci. (London). 38: 629.

13. Cort. J. H., V. Pliška, and T. Douša. 1968. The chemical nature and tissue source of natriuretic hormone. Lancet 1: 230.

14. Richet, G., and A. Hornych. 1969. The effect of an expansion of extracellular fluids on net $\mathrm{Na}$ flux in the jejunum of rats. Nephron. 6: 365.

15. Gutman, Y., and F. Benzakein. 1970. Effect of saline loading on absorption from the cat ileum in vivo. Isracl J. Med. Sci. 6: 195.

16. Hydén, S. 1955. A turbidometric method for the determination of higher polyethylene glycols in biological materials. Kungl. Lantbrukshögskolans Ann. 22: 139.

17. Gornall, A. G., C. J. Bardawill, and M. M. David. 1949. Determination of serum proteins by means of the biuret reaction. J. Biol. Chem. 177: 751.

18. Levinson, R. A., and H. P. Schedl. 1966. Absorption of sodium, chloride, water, and simple sugars in rat small intestine. Amer. J. Physiol. 211: 939.

19. Fordtran, J. S. 1966. Marker perfusion techniques for measuring intestinal absorption in man. Gastroenterology. 51 : 1089.

20. Snedecor, G. W. 1956. Statistical Methods Applied to Experiments in Agriculture and Biology. The Iowa State University Press, Ames. 5th edition.

21. Davis, B. B., Jr., and F. G. Knox. 1970. Current concepts of the regulation of urinary sodium excretiona review. Amer. J. Med. Sci. 259: 373.

22. Visscher, M. B., R. H. Varco, C. W. Carr, R. B. Dean, and D. Erickson. 1944. Sodium ion movement between the intestinal lumen and the blood. Amer. J. Physiol. 141: 488.

23. Visscher, M. B., F. S. Fetcher, Jr., C. W. Carr, H. P. Gregor, M. S. Bushey, and D. E. Barker. 1944. Isotopic tracer studies on the movement of water and ions between intestinal lumen and blood. Amer. J. Physiol. 142: 550 .

24. Loeschke, K., C. J. Bentzel, and T. Z. Csáky. 1970. Asymmetry of osmotic flow in frog intestine: functional and structural correlation. Amer. J. Physiol. 218: 1723.

25. Chinard, F. P., and T. Enns. 1955. Relative renal excretion patterns of sodium ion, chloride ion, urea, water and glomerular substances. Amer. J. Physiol. 182: 247.

26. Windhager, E. E., E. I. Boulpaep, and G. Giebisch. 1966. Electrophysiological studies on single nephrons. Proc. Int. Congr. Nephrol. 3rd. 1: 35.

27. Bentzel, C. J., B. Parsa, and D. K. Hare. 1969. Osmotic flow across proximal tubule of necturus: correlation of physiologic and anatomic studies. Amer. J. Physiol. 217: 570.

28. de Rouffignac, C., and F. Morel. 1969. Micropuncture study of water, electrolytes, and urea movements along the loops of Henle in Psammomys. J. Clin. Invest. 48: 474.

29. Maude, D. L. 1970. Mechanism of salt transport and some permeability properties of rat proximal tubule. Amer. J. Physiol. 218: 1590.

30. Ussing, H. H., and K. Zerahn. 1951. Active transport of sodium as the source of electric current in the shortcircuited isolated frog skin. Acta Physiol. Scand. 23: 110.

31. Leaf, A., J. Anderson, and L. B. Page. 1958. Active sodium transport by the isolated toad bladder. J. Gcn. Physiol. 41: 657.

32. Maetz, J. 1969. Seawater teleosts: evidence for a sodium-potassium exchange in the branchial sodium-excreting pump. Science (Washington). 166: 613.

33. Ussing, H. H. 1966. Anomalous transport of electrolytes and sucrose through the isolated frog skin induced by hypertonicity of the outside bathing solution. Ann. N. Y. Acad. Sci. 137: 543.

34. Farquhar, M. G., and G. E. Palade. 1963. Junctional complexes in various epithelia. J. Cell Biol. 17: 375

35. Diamond, J. M. 1971. Standing-gradient model of fluid transport in epithelia. Fed. Proc. 30: 6.

36. Oschman, J. L., and M. J. Berridge. 1971. Structural basis of fluid secretion. Fed. Proc. 30: 49.

37. Higgins, J. T., Jr. 1971. Mechanisms of intestinal efflux during extracellular fluid expansion. Clin. Res. 19: 533. (Abstr.)

38. Humphreys, M. H., and L. E. Earley. 1971. Mechanism of depression of intestinal sodium transport during saline infusion. Clin. Res. 19: 195. (Abstr.) 